\title{
An Investigation into the Underlying Factors Responsible For Low Performance of Educational System: A Nigerian Perspective.
}

\author{
Orenaiya Solomon Adewale \\ School Of Basic Studies, Ministry Of Education, Science and Technology; And Teaching Service Commission, \\ Ogun State, Nigeria. \\ Faculty Of Major Languages Studies (FPBU), Universiti Sains Islam, Malaysia, Nilai Post Code 71800, Negeri \\ Sembilan, Nilai, Malaysia.
}

\begin{abstract}
One of the major ways of improving the quality of human resources is to provide education to citizens, while the indices for measuring its performance are the level of quality of input, processes and the products/outcomes. The low quality level recorded is connected with multiple factors arising from teaching staff, Government(teaching facilities/teaching resources, funds),parents, students and society.Athough,external variables such as policies, political unstability,economy recession and technology advancement cannot be totally excluded. But, the shortages of teaching staff, ineffective supervision, less teaching resources, examination malpractices and misappropriation of funds) will be focused by this paper considering the nature,causes,consequences and remedies.Therefore, research questions on the measuring indices of education are formulated while tools for collection of data are questionnaires and interview with the results analysis in percentages aligning to qualitative than quantitive.A visible results showed that misappropriation of funds constitute the moderating indice which can eliminate or drastically reduce other indicators. At the end, suggestions were made while further studies on ineffective supervision of educational institutions can be extensively explored as a strategic roadmap.
\end{abstract}

Keywords: factors, low performance, education system and Nigeria.

\section{Introduction}

The issue under discourse is a gender scenario but Africa is worst -hit of which Nigeria has its own largest share because of our population and strategic position of Nigeria in the World of phenomena an uncontrolled setback in the educational performance of country like Nigeria can be heavily devastating to the entire black race and Africa, this is seen in the capital flight out of Nigeria to other part of the world as well as some African countries such as Ghana, South Africa, Ivory coast,Tanzania,Morocco,Egypt and Algeria to mention a few. The aforementioned countries is supposed to imitate good indices of educational performance from Nigeria, but the reverse is the case, hence low quality of education is more pronounced in Nigeria to have prompted investigation into it.The forecasts from educational planners and administrators was re-echoed in the studies carried out by Omotosho(1990), Onyechere and Ijaiya(2004) focused on student enrolment, teaching staff preparation, retention and enhanced performance to be incorporated into education budgetary allocation that is commensurate with strict adherence to stated purpose in order avoid enormous leakages in the country's educational system.

The importance of education is crucial as a catalyst to national development can be traced to National Policy on Education at the primary, secondary and tertiary levels respectively, also education is a tool to equip citizens for meaningful existence and most importantly, education serve as a connector and bedrock to which sciences, technology, industry, technology and culture are all embedded in the education. It must be emphasized that functional education is a mirror to identify, develop citizens for knowledge and skills for achieving progressive and democratic society. In a research study conducted by Isola\&Alani (2013) revealed that the provision of quality education is one of the sources of improving human quality resources. The stated indices for measuring standard and qualities of education are full of unpalatable evaluation reports, depth of examination malpractices in public examination is perplexing because it is a common sight for teachers and students to cheat in tests and examinations, says Onyechere (2004).

The question on the minds of the writer and other concerned citizens is why are the importance/roles of education not realizable in Nigeria? comparable to some West African Countries, Asia and other part of the World prompted the down-to earth investigation of nature, causes and possibly devise solution. 


\section{Statement Of The Problem}

The exodus movement of Lecturers, instructors and students out of the country to lowly rated countries in term of human and materials resources is a worrisome situation to the quality of education system in Nigeria. In another related instance, post graduate students from Nigeria tops the number of students seeking admission and are being offered admission among the foreign students. What this portends is that there is human resources and ingenuity flight to other countries. This relatively improves the economy of the host countries and upgrade the quality of their education even if it does not merit it.The open embarrassment and dented image of Nigeria when a quarter of Nigerian Youths seek foreign scholarship to study abroad is a testimony to low performance of our education. In addition, the number of students' failure in academic grades after completion of instruction in schools is high. Above all, where is the justifiable reason for classifying Nigeria as a giant in Africa and highly gifted black race in the world when our education assessment is low?

\section{OBJECTIVES OF THE STUDY}

1. To find out the reasons responsible for low performance of Nigeria's education.

2. To identify the consequences of low education performance in Nigeria.

3. To bring back the lost glory of education standard to Nigeria through transformation of Nigerians.

4. To improve the quality of education in Nigeria.

\section{RATIONALE OF THE STUDY}

1. To produce Nigerian students who is academically good.

2. To attract foreign students into Nigeria's educational system.

3. For realization of functional education in Nigeria.

\section{SIGNIFICANCE OF THE STUDY}

-The main significance of investigation into the factors responsible for unfavorable level of educational performance is to sensitize all stakeholders of educational administration to discharge their responsibilities with utmost integrity. While parents, planners, administrators and implementations and providers should employ reflective technique in attitudes and behaviours in their responsibilities in order to rebrand our educational system.

-To stop growing decline of education system in Nigeria.

-To improve the standard of education system in Nigeria.

-To increase the gross domestic product (GDP) of the economy through education.

-To contribute towards building of Nigeria and Nigerians of our dreams in all aspect of human endeavor.

\section{THEORETICAL CONSTRUCTS:}

There are two theories surrounding the issue at stake, these two theories are systems theory and contingency theory.

\section{(A) - SYSTEMS THEORY}

The history of system theories includes contributions from Ludwig von Bertalanffy (1925-1926), Kenneth Boulding, Kurt Lewin etc. Systems theory provides a field of inquiry. A system theory draws on the body of knowledge derived from general systems theory and its application in the domain of human activity systems. Systems theory is an approach in which related components of a problem were investigated in isolation from one another, a value of integration of parts of a problem and that a problem cannot be solved in isolation. A system may be described as a complex of interacting components together with the relationships among them that permit the identification of boundary-maintaining entity Therefore, systems theory is composed of a problem (a situation that is not working properly and needs improving and a solution to be determined), goal setting, input, output and feedback.

\section{(B) - CONTIGENCY THEORY}

This theory asserts that during decision making process, all dimensions/areas of the prevailing circumstance must be thoroughly diagnosed and act on the one having direct relation to it.It is beneficial to apply participative and facilitative leadership style.

\section{Content And Discussion}

The main causes of low performance of education system in Nigeria will be illustrated in a conceptual framework shown below; as Figure 1 


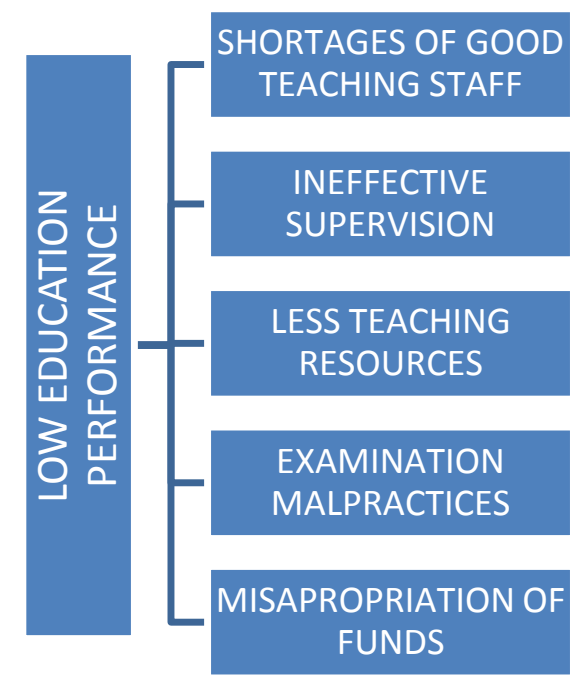

\section{SHORTAGES OF GOOD TEACHING STAFF}

Teaching staff is the central component of educational industry because the quality of a country's education cannot rise above the level of teachers. A teacher is a person who had gone through required and essential courses, principles and practices of education in educationally and professionally institutions of higher learning and certified to be qualified to teach at any levels of education in Nigeria. A good teaching staff must be able to exercise effectiveness in organization clarity, synthetic approach, dynamism\&enthusiasm, instructorgroup interaction and instructor-students interaction. The arrays of colleges of education, faculties of education in Nigeria's universities had capacities to train and produce qualified and quality teaching workforce. This is manifested when large number of teaching staff applicants besiege the offices of States "Teaching Service Commission across Western part of Nigeria where substantial vacancies exists which eventually results into enrichment of personnel in charge of recruitment with grafication,money and personal sacrifices etc. and also increase the population of private owned schools, although shortages of good teaching staff were more pronounced in public schools .The shortages of good teaching staff is caused by irregular/nonpayment of salaries/emoluments and high turnover rates of teachers. Ingersoll (2000) added that it is not an insufficient product of training schools or qualified teacher candidates that causes teaching staff shortage; rather it is the high rates of teacher turnover. Turnout rate is a measure of how large number of teaching staff leaving teaching profession is higher than the rate of recruitment because experienced and quality teacher leaves the job as evidences are abounds that staying long and learning on the job increases level of instruction which affects student learning. Although, the writer is not advocating for stoppage of recruitment of new teaching staff as some members of staff will naturally leave and must be replaced for balancing but where reason relating to salaries and conditions of service are responsible for higher exit of experienced teachers will create a big gap to retain and possess good teaching staff. Research results attested that most of the good teaching staff leave (Boser, 2000, Hare\&Heap, 2001) and flourish in next endeavors, including establishment of schools and conducting educational services. In attempt to fill large gap due to voluntary retirement/exit of good teaching staff leads to unqualified academically and unprofessionally candidates are recruited while less qualified and professional teaching staff are not recruited while some candidates without required qualification in subjects assigned to teach. Several studies had shown that teacher expertise is the most important factor in students' achievement. The effects of teacher quality complicates the achievement level of at-risk students(Haycock 1998),Darling-Hammond\&Ball,(1998) that the effects of teacher quality are long lasting,cumulative.The direct shortcomings of high level of new recruitment has great impact on academic achievement(Standardized Achievement Test) which is a criterion for measuring quality of education. Furthermore student learning is badly affected because methodology and teaching skills of good quality instructions require long time to acquire, and build up ineffectiveness of teaching staff (Hawley, 2000).Also, it encourages recruitment of mediocre, encouragement of examination malpractices, wastage of resources and production of candidates with low academic grades.

However, there are several reasons responsible for shortage of good/quality teaching staff beside high turnover rate which job dissatisfaction, school leadership styles, limited opportunities in teaching profession, poor job conditions (lack of comfort ability loans, respect and recognition etc.). 


\section{EXAMINATION MALPRACTICES}

This is an illegal conducts exhibited by students, teachers, parents, invigilators, supervisors, security operatives, printers and examination bodies or personnel involved in conducting examinations before, during or after examination. Examination malpractices is a menace or ills perverting the nooks and crannies of every levels of educational institutions, the nature is such that examination had been abused in a purpose it was not meant to serve. A review of importance of examination as a tool or means of diagnosing difficulties in learning and teaching, evaluating effectiveness of teachers' level of classroom instructions delivery, identifying exceptional and for promoting students from one class/level to another. It is just unfortunate we place too much emphasis on promotional usage to the detriment of crucial importance or purpose of examination that resulted in mass examination malpractices by teachers, students, parents, school administrators and policy makers even though the World Bank Group (2001) reported that teachers and school reputations is a correlate on the success of students in public examinations. The writer totally disagree on the whole statement except where teaching staff effectively teach to equip the students for enabling good performance as found in some Federal Government Schools and religious institutions/schools .A recent published examination results in some states' schools without teaching resources(lack of laboratory facilities and inadequate teaching staff in sciences ) recorded outstanding performance in academic grades is an indicator of depth of examination malpractices growing into same attitudes exhibited in qualifying examinations such as West African Senior School Certificate Examinations(WASSCE) and Joint Admissions and Matriculation Board(JAMB)and internal examinations in schools.

The various causes of examination malpractices are ineffectiveness of teaching staff(Mcleod 1995),poor supervision of examination by personnel of ministry of education, ineffective invigilation of tests by teachers, undue pressure from parents, defective classroom organization of chairs and tables/seating arrangements, non-provision of hall to write examinations, parental influence on teachers ,compromisation by school leadership, students poor attitude to studies and classroom instructions as well as societal influence and negative impact of social media and technology.

Examination malpractices will not be completely diagnosed without identifying various forms of malpractices ranging from dictation of answers to students by teaching staff,acess to examination questions before official dates and time, allocation of undeserved marks/grades, leaving students unsupervised during examination and tests by teaching staff, teacher's writing on chalkboards for students, aiding and abetting in distribution of prepared answers, imposition of candidates, copying of answers on question papers among students, exchange of answer booklets and question papers among students and teaching staff, and sale of question papers by supervisors and security agents. From this analysis, teachers were the most culprits, closely followed by students; Derry (2004) maintained that students and youths cheat because they have prioritized entertainment and pleasure at the expense of their books and classroom learning. This also generates support and data from writer's observation, questionnaires collation and interview to arrive at this bar chart illustration below;

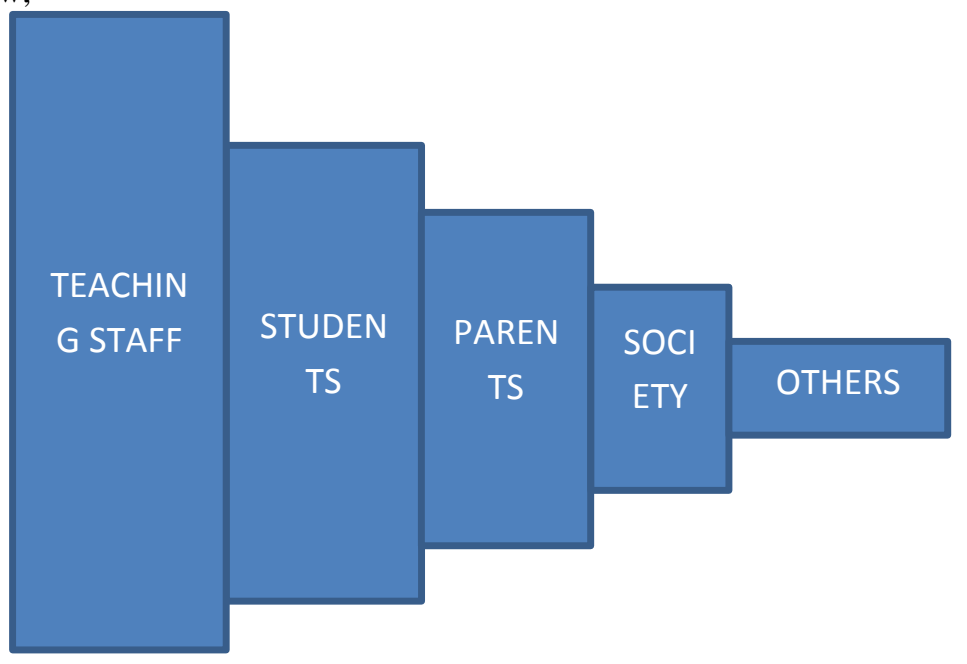

Figure 2: LEVELS OF EXAMINATION MALPRACTICES IN NIGERIAN SCHOOLS.

The gravity of levels of examination malpractices is a correlate to low performance of education in Nigeria would be viewed from the consequences/effects in production of thugs/indiscipline citizens in the society, less personal fulfillment\&un-fulfilled dreams, discouragement of hard work and integrity, denial of admission opportunities to hard work students, impediments to productive classroom learning, poor image of teaching staff 
and incompetency of tasks in subjects/certificates acquisition, finally low recognition of products and certificates obtained from such system.

\section{INEFFECTIVE SUPERVISION}

What matters most is not where teachers come from but what they do in the classroom. Cawood\&Gibbon (2000) defines supervision in terms of leadership aims at renewal of objectives, professional growth and educational improvement. Supervision is an act of monitoring an organization to ensure appropriateness to meet all of the different requirements put in place for it, and this must be carried out continuously. Supervision looks closely at something with an intention to provide leadership to school teachers in order to improve teaching methodologies and educational system. Supervision is mainly concerned for improvement of standards and quality of education. A lot reasons might be responsible for ineffectiveness such as low frequency of monitoring, inadequate duration of monitoring, lack of motivation, on -provision of conducive working conditions and inadequate academic/professional qualifications. Therefore, effectiveness in instructional delivery and monitoring is a key influence on economic well-being of the nation and then equip the students to contribute significantly to complex and changing society and that effectiveness in improving the quality of education depends on the emphasis placed on functions of evaluation, guidance,training and wellstaffed and working in close partnerships with other agencies for reform and development within the educational service.

\section{LACK OF TEACHING RESOURCES}

These are learning materials for conveying knowledge, skills, enabling further discoveries to students. The purpose of teaching resources on educational system is to produce students whose performance are rewarding and competitive to outside world of student and educational pursuit but where there is none or inadequacy of teaching materials, it results into examination malpractices and portrays low standard of education. This is in support of, Ibia (2006).Examples of teaching resources or teaching materials are charts, maps, laboratories, laboratory assistants, teaching aids. textbooks, chairs, tables and libraries.

\section{MISAPPROPRIATION OF FUNDS}

This is an act of diverting appropriated fund (money) for specific project to another project without recourse to procedural act, although the acceptable cause and acceptable reason is not known because every ministry including education /agencies associated with education expenditure is considered and allocated with financial resources. This retrogressive practice is more prevalent in education and health which is responsible for endless strikes and closure of schools. Institutions and establishments connected to education industry is thought to be closely related to teaching staff' high turnover rate of good teaching staff, non- provision of teaching resources, ineffective supervision by education inspectors because instruments of work are not provided, poor condition of service, culminating in examination malpractices and corruption perverting all segments/levels of education system in Nigeria, thus low quality of education is established.

\section{Conclusion}

Education is a catalyst for national development of human and material resources. The provision of qualitative education is not dependent on the huge size of allocated finance but on the timely release and usage for the purpose appropriated at the right time to ensure stay of experienced and professional teaching staff who will employ methodological and skill competencies for the usage of teaching resources. Thefore,co-operative and collaborative effort is needed for allocation of funds for provision of qualitative education, for provision of material resources and effectively supervised to achieve the goals and objectives of citizens and Nigeria. It is not that education is extremely expensive but timely release of available fund with utmost trust and integrity during usage and implementation of any educational policies and programs is a measure of quality, efficiency, validity and reliability for all and sundry.

1. Mentoring of beginning teachers.

\section{Recommendations and Suggestions}

2. Improvement of working conditions of teaching staff.

3. Good mastery of subject with good teaching skills and modern learning techniques.

4. Improve teachers 'retention by gradual increase in pay after four to five years to meet growing needs of teaching staff.

5. Re-organization of inspection/supervision department for effectiveness with additional number of staff.

6. The frequency and duration period of supervision should be increased for increased standard of education.

7. Transport allowances and incentives should be readily available for supervision teams.

8. Functional provision of teaching resources in educational schools. 
9. Parents should encourage their children to study at home and discourage wastages of time on excessive watching of television and entertain.

10. Organization of seminars, workshops and developmental meetings with parents, teachers and students on good study habits and good ethics on examination/school tests.

11. Timely release of funds for approved educational projects,

12. Working together of all agencies and departments of ministry of education to achieve personal and corporate objectives/goals.

\section{References}

[1]. Omotosho, H.M (1990).The face of examination malpractices in Nigeria.WAEC News,4(3).3-5 and a stigma on school effectiveness in Nigeria.

[2]. Ijaiya, N.Y.S (2004).Agents of Examination Malpractices in Nigeria public examinations. The strongest links in Nigeria. A publication of the National Association of Educational Researchers\&Evaluators,5(1)55-62.

[3]. Isola\&Alani (2013).Examination Malpractices in Paul Salisu Ojonemi et al: Challenges to human resources development in Nigeria. International journal of capacity building in education and management.(IJCBEM)Volume 2,No 1,91-101.

[4]. Onyechere, I(2004).Cheating: A world-wide problem. In comes in at least 33 ways All.Africa.com

[5]. Bertalanffy, L.V (1925).On the making of a system theory of life: A conceptual Connection.

[6]. Ingersoll(2000).Turnover among mathematics and science in the US,http://www.ed.gov/ints/maths/Ingersoll p.doc

[7]. Boser,P(2000). Who should teach? Education Week 19(18),8-9 and Quality Counts. Journal of Technology Education, Volume 19, No 1 by Fall 2007.

[8]. Haycock(1998).Good teaching Matters A Lot published by by the center for the future of teaching and learning,137 mission street, suite 220,Santa Cruz.CA 95060. Volume 3, Issue 2.

[9]. Darling-Hammond\&Ball (1998).Keeping good teachers. Educational Leadership,60(8)2003, 6-13.

[10]. Hawley,E(2000). Teacher Turn Over: A conceptual Analysis published in the International Journal of Educational Leadership preparation.

[11]. WorldBankGroup (2001).The nature of public examinations. Retrieved on March $8^{\text {th }}$ 2014.http://www.I.worldbank.org/education/exams/nature.asp

[12]. Mcleod,J(1995).Nature and causes of examination malpractices. Published by educational, leadership, 46 volume 5 ,issue 2

[13]. Derry,T.(2004).Remote causes and counseling implications of examination malpractices in Nigeria.WAEC.Lagos,Nigeria published by Nsisong A.Udoh in Student Pulse, The International Student Journal 2011,Vol 3,No 10 pages 1-3

[14]. Cawood,J\&Gibbon,J(1990,2000).Educational Leadership: staff development,Capetown,Nasou.

[15]. Ibia, E, Ibia (2006).Sociological Foundations of Nigerian Education, Oyo: Abaam publishing Company. 